\title{
From Guardian Angels to Pests to Korean: The United States Forces and Their Criminal Acts in Korean Society
}

\author{
Daehoon Han \\ Department of Psychology and Sociology, Texas A \& M University, Kingsville, TX, USA \\ Email: Daehoon.han@tamuk.edu
}

Received 5 March 2016; accepted 11 April 2016; published 14 April 2016

Copyright (C) 2016 by author and Scientific Research Publishing Inc.

This work is licensed under the Creative Commons Attribution International License (CC BY). http://creativecommons.org/licenses/by/4.0/

(c) (i) Open Access

\begin{abstract}
Previous literature suggested that crimes committed by the U.S. military forces in Korea (USFK) against innocent Koreans became one of the most serious social issues in Korean society, thereby they became the social pest rather than the guardian angel for many Koreans because of the ceaseless pattern of their horrendous acts against innocent Koreans. While much previous research paid attention to the general characteristics of crime by the USFK in Korea, relatively less attention was given to the reason why the USFK became the nuisance to many ordinary Koreans. In order to better understand this social problem caused by the USFK and their criminal acts, thus, this study focused on how Korean judicial authorities exercised their power to deter the USFK from committing any possible crimes against Koreans during their time serving in Korea. Based on analyzing the set of secondary data sources, the punishment imposed on crimes committed by the USFK was so lenient that it was not effective to curb their criminal acts, and it was closely related with the lack of certainty of punishing the USFK. This study also found out that the Status of Forces Agreement (SOFA) made the Korean judicial authorities incapable of controlling many criminal wrongdoings by the USFK because of the several unfair clauses that infringed Korean judicial sovereignty and paralyzed the function of its judicial power.
\end{abstract}

\section{Keywords}

Deterrence, Military Crime, Judicial Exercise

\section{Introduction}

On Oct. 28, 1992, Ms. Kum-E Yoon, a Korean woman, was murdered in Dongduchan, about 30 km north of 
Seoul, Korea, by Pvt. Kenneth Markle, the U.S. military servicemen with the U.S. Army's 2nd Division in Dongduchan city (Kim, 1992). She was found with a cola bottle embedded in her uterus, an umbrella stuck 27 $\mathrm{cm}$, into her rectum, and detergent powder poured over her bloody body.

The unmerciful and cruel crime, committed by a United State military serviceman whose commander insisted that they came here to defend the freedom of Korea, shocked and angered the Korean people once again, as the worst of a long string of crimes perpetrated by the United States Forces Korea (USFK) during the last 60 years. The Kum-E Yoon case awakened the Korean people to undertake fundamental measures to prevent such USFK crimes. Forty six organizations from various circles of Korean society including political parties, women, clergy, students, workers, and farmer, organized a Joint Commission for Counter-Measures Regarding the Miss Kum-E Yoon murder case (Ko, 2011).

The Commission staged such activities as press conferences, visits to the Korean prosecutor and the Ministry of Justice, the U.S. Ambassador and the Commander of U.S. Army in Korea, and a signature campaign demanding the sincere attitude of the official apology of the Commander of the U.S. Army in Korea and the U.S. Ambassador. Not only the Korean people but also many distinguished people and organizations in U.S., had supported the movement and promised action in solidarity (Ko, 2011). As a result, at the district court, the truth of the case was proved, and the murderer was sentenced to life imprisonment. However, his term was reduced to 15 years imprisonment at the appeal court, and he made another appeal to the Supreme Court while being imprisoned not in Korean prison but in the U.S. Army prison in Pyungtaek. Even if he committed this horrendous crime against an innocent Korean citizen, but Korean law enforcement could not exert its judicial power over this case. Even he was released on parole and left for the U.S. the next day of parole, and Korean government had never tried to identify the address of the paroled U.S. soldier in the U.S. since that time (Go, 2011).

This was just one of countless incidents that the USFK had inflicted on many innocent Koreans and represented how crimes committed by the USFK had been handled by Korean judicial authorities since they were fully stationed in Korean at the end of the Korean War (Xu, 2007). And, even if the characteristics of alliance between the U.S. and South Korea were fundamentally altered by the end of Cold War by the 1990s that led to the reduction of the size of the USFK (Baker, 2004, see Figure 1), they were still the one of the major causes of an upsurge in the anti-American sentiment because of many gruesome crimes they committed (Jung, 2008).

Over the years, clashes between the USFK and local South Koreans have caused emotional controversies and occasionally resulted in pervasive anti-American sentiment in Korean society (Snyder, 2009). The anti-American sentiment in South Korea is an issue that specifically arises from the crimes against South Koreans perpetrated by the USFK (Kim, 2005). For instance, in 2002 thousands of South Korean protesters demanded the U.S. to hand over its servicemen who accidentally killed two South Korean schoolgirls while driving an armored car for a training exercise in 2002 after being adamantly refused by the US ultimately to surrender jurisdiction that led to the acquittal of the two responsible soldiers under a US military court (Deutsch, 2008), and this seeming pattern of unfairness and injustices sparked the national psyche of South Korean public and made them target the USFK and foreigners to open aggression, intimidation, and discrimination because the majority of Koreans

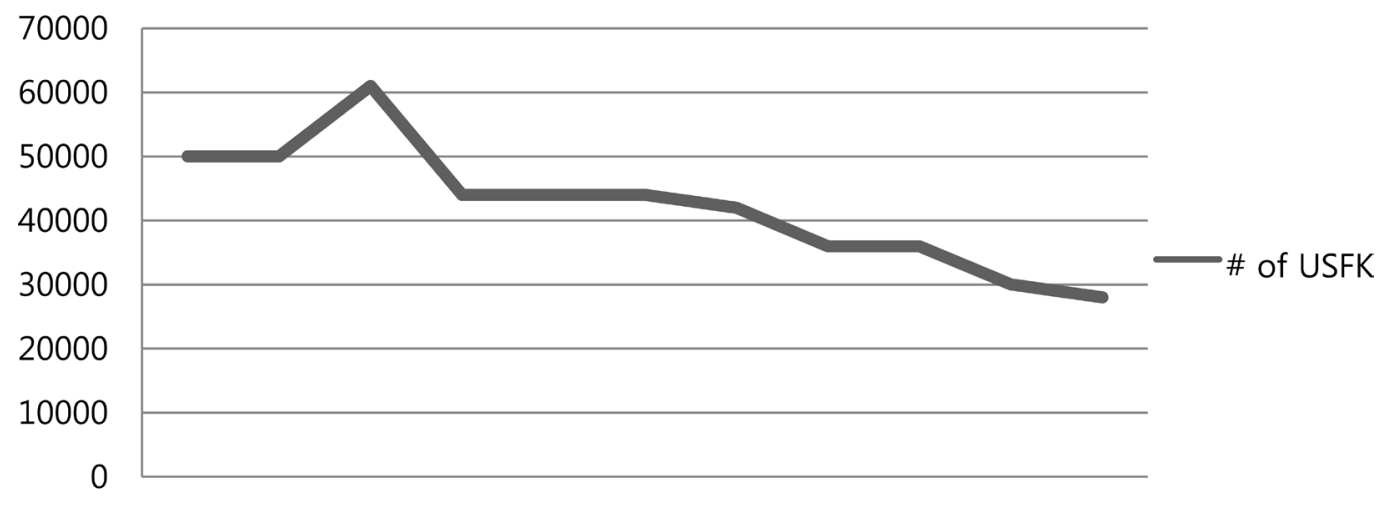

19601965197019751980198519901995200020052010

Figure 1. Line graph showing the number of U.S. Military Forces in Korea. From "Base structural report, United States 2010”, by the U.S. Department of Defense (2010). 
strongly believed that this vicious phenomenon was caused by the massive presence of the USFK (Deutsch, 2008).

In this last half century, the presence of the USFK has been acknowledged as a vital key to underpin peace on the Korean peninsula. However, when Soviet Union became the capitalistic Russia, a debate about whether or not the USFK should remain in Korea emerged in Korean society (Cho, 2003). This debate was even spotlighted when the relentless social problems were created by some of the USFK, and many Koreans became more skeptical about the necessity of the presence of the USFK for the security of Korean peninsula. Thus, it strongly suggests that the relationship between two countries is still maintained as being firm base in the official diplomatic level, but this friendly mood sharply disappeared in the public atmosphere, and criminal wrongdoings by the USFK have been considered as the biggest causal factor to make this negative public attitude toward the USFK despite of the fact that there has been the gradual decrease in the number of the USFK in accordance with the U.S. government's plan on restructuring U.S. forces in the world (Kirk, 2002).

Therefore, the main purpose of this study is to examine the circumstance in that the USFK became the social pest for Korean society rather than the guardian angels for Korean people because of their status as the breeding ground for many heinous crimes in Korean society. In order to examine this social issue, thus, this study focuses on the pattern of the ineffective law enforcement by Korean judicial authorities to handle those criminal wrongdoings by the USFK. Also, the Status of Forces Agreement (SOFA) ${ }^{1}$ and its role on making Korean judicial power incompetent in controlling the USFK crimes is presented in detail because many unfair features of this international treaty embolden the USFK to keep committing criminal wrongdoings against innocent Korean people without fear.

Before touching this main research agenda, however, I first of all will present a number of facts to shed light on how serious the criminal wrongdoings the USFK have committed against Korean people.

\section{U.S. Military Crime in Korea}

The presence of the USFK became a major social problem for Korean society because of their consistent involvement in criminal wrongdoings that affected the lives of many Korean people directly or indirectly. According to the Korean government's official statistics, 50,082 crimes were committed by the USFK and their families from 1967 to the end of 2005, and 56,904 U.S. servicemen and their families were involved (National Campaign for Educational of Crimes by U.S. Troops in Korea, n.d.).

The statistics even imply that the actual figure would be higher if taking into account crimes by the USFK before 1967 because Korean judicial authorities could not exercise jurisdiction for the USFK who committed crimes in Korea under the implementation of SOFA. In other words, from 1945 to 1967, the U.S. had full jurisdiction in handling crimes committed by the USFK.

Furthermore, even fewer U.S. servicemen were prosecuted by the Korean judicial authorities. Study by Korean Ministry of Justice shows that among the 39,452 cases (45,183 servicemen involved) of crimes committed by the USFK from 1967 to 1987 the Korean judicial authorities were able to exercise its jurisdiction only in 234 cases, punishing only 351 servicemen. About $50 \%$ of those prosecuted were convicted of serious crimes, such as rape and robbery (84 servicemen were convicted of rape, following 89 servicemen of murder and robbery), and the condition was not significantly improved in 1990s (National Campaign for Educational of Crimes by U.S. Troops in Korea, n.d.).

As shown in Table 1, about 700 crimes were committed on average per year by the USFK and non-military personnel in Korea in 1990s, but only 3.8\% of them (excluding non-military personnel) on average were put on trial in Korean courts (National Campaign for Educational of Crimes by U.S. Troops in Korea, n.d.). Thus, when compared to the earlier times, there was no significant improvement in the pattern of criminality of the USFK despite the SOFA revision in 1991 that made the Korean judicial authorities to better handle crimes by the USFK.

Furthermore, the condition is much more serious when we consider the types of crime committed by the USFK. As indicated in Figure 2, felony cases, such as rape, aggravated assault, murder, accounted for more than $40 \%$ of total criminal cases in average between 2007 and 2010, and they even accounted for the half of total criminal cases in 2010. Thus, when taking into account of the quantitative and qualitative characteristics of

\footnotetext{
${ }^{1}$ Status of Forces Agreement (SOFA) is an agreement between a host country and a foreign nation stationing forces in that country. In this paper, SOFA is meant to be the agreement between Korea and the U.S. over the issue of the U.S. Military Forces stationed in Korean territory.
} 
Table 1. Judiciary Practice between Korea-U.S. SOFA Crimes between 1992 and 2000.

\begin{tabular}{|c|c|c|c|c|c|}
\hline \multirow{2}{*}{ Year } & \multicolumn{4}{|c|}{ Number of Cases and Personnel } & \multirow{2}{*}{$\begin{array}{c}\text { Korean Judicial Practiceon } \\
\text { USFK (\%) }\end{array}$} \\
\hline & Case and Personnel & Sub Total & Military Servicemen & Civilian and Family & \\
\hline \multirow{2}{*}{1992} & Case & 754 & 642 & 112 & $10(1.6)$ \\
\hline & Personnel & 849 & 725 & 124 & $10(1.4)$ \\
\hline \multirow{2}{*}{1993} & Case & 802 & 624 & 178 & $13(2.1)$ \\
\hline & Personnel & 927 & 721 & 206 & $21(2.9)$ \\
\hline \multirow{2}{*}{1994} & Case & 896 & 711 & 185 & $18(2.5)$ \\
\hline & Personnel & 1025 & 812 & 213 & $25(2.4)$ \\
\hline \multirow{2}{*}{1995} & Case & 903 & 694 & 209 & $41(5.9)$ \\
\hline & Personnel & 999 & 775 & 224 & $52(6.7)$ \\
\hline \multirow{2}{*}{1996} & Case & 702 & 526 & 176 & $18(3.4)$ \\
\hline & Personnel & 767 & 578 & 189 & $23(4.0)$ \\
\hline \multirow{2}{*}{1997} & Case & 689 & 543 & 146 & $31(5.7)$ \\
\hline & Personnel & 743 & 577 & 166 & $35(6.1)$ \\
\hline \multirow{2}{*}{1998} & Case & 660 & 518 & 142 & $20(3.9)$ \\
\hline & Personnel & 734 & 576 & 158 & $28(4.9)$ \\
\hline \multirow{2}{*}{1999} & Case & 761 & 562 & 199 & $20(3.6)$ \\
\hline & Personnel & 824 & 612 & 212 & $31(5.1)$ \\
\hline \multirow{2}{*}{2000} & Case & 506 & 311 & 195 & $23(7.4)$ \\
\hline & Personnel & 575 & 209 & 209 & $27(7.4)$ \\
\hline \multirow{2}{*}{ Total } & Case & 6673 & 5131 & 1542 & 194 (3.8) \\
\hline & Personnel & 7443 & 5742 & 1701 & $252(4.4)$ \\
\hline
\end{tabular}

Source: National Campaign for Educational of Crimes by U.S. Troops in Korea, (n.d.).

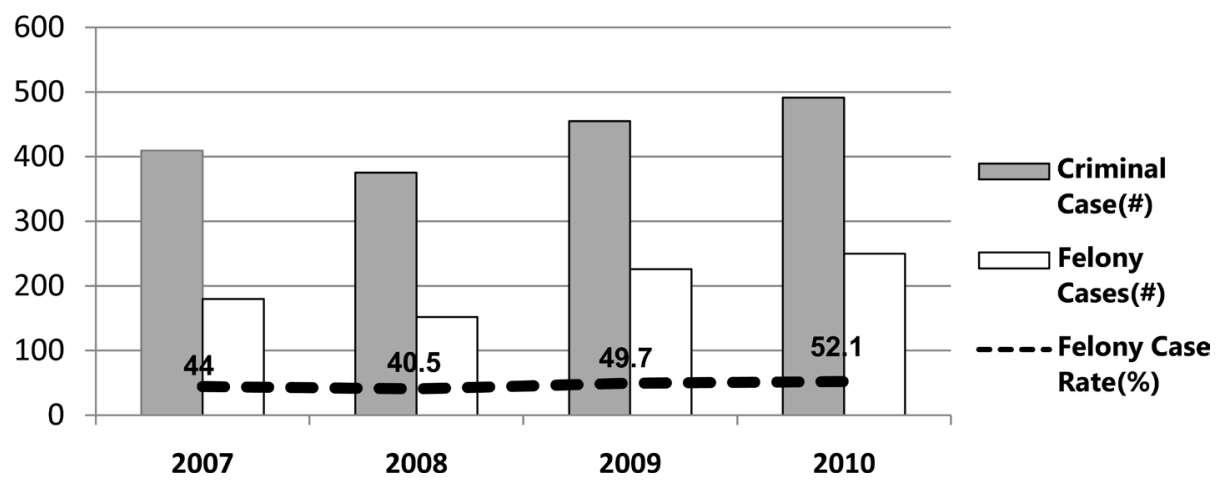

Figure 2. Bar and line graph showing criminal cases by U.S. Military Forces in Korea. From “Annual survey of crimes in Korea”, by National Police Agency, (n.d.).

crime committed by the USFK, it clearly indicates that the USFK became a social nuisance for many Koreans, who no longer welcomed the presence the USFK. In order to better understand why the USFK became the major perpetrator of many serious crimes, a theoretical perspective is introduced in the next section.

\section{Theoretical Explanations on the Cause of Crime}

There are many theoretical assumptions that have different approaches in seeking answers to a question of why people commit criminal wrongdoings, and the deterrence theory focuses on personal choices based on the conception of rational choice as a main element of engaging people in criminal acts.

There are central points of this theoretical perspective, such as: 1) Every human being is a rational actor who 
freely chooses all behavior, both conforming and deviant, based on their rational calculations; 2) Rational calculation involves a cost benefit analysis and; 3) Every human being chooses all behavior that assures the maximization of individual pleasure and the minimization of the potential pain or punishment that will follow an act that is judged to be in violation of the social good (Beccaria, 1963; Bentham, 1948; Hobbes, 1962).

In addition, Beccaria (1963) also argued that the state is responsible for maintaining order and preserving the common good through swiftness, severity, and certainty of punishment that are the key elements in understanding a law's ability to control human behavior. Hobbes (1962) ascertained that the human being is not either good or bad but commonly motivated to engage in deviant acts when criminal acts are frequently beneficial. So, achieving a maximum outcome of controlling criminal acts is always accompanied by a punishment that should be unpleasant, certain, and swift (Gibbs, 1968; Beccaria, 1963). In other words, crime is controlled by negative means in that a person has no desire to commit crime when the advantages are offset by the costs in committing criminal acts, and the costs should be assured by unpleasant, certain, and swift nature of punishment on a person who commits criminal acts (Gibbs, 1986). Thus, the deterrence theory claims that whether or not a person decides to engage in criminal wrongdoings is totally dependent on 1) how painful a punishment is inflicted on a person who commits criminal acts; 2) how definite a punishment is imposed on a person without considering any other alternatives and; 3) how expeditious a punishment is made for a person without delay (Beccaria, 1963; Tittle, 1969).

Based on these previous researches, therefore, it is assumed that the less painful, swift, and certain a punishment is, the more a person likely to commit criminal acts. And, a study presented here examines whether or not the USFK is deterred from committing crimes against innocent Koreans because of the painfulness, swiftness, and certainty in the Korean law enforcement. Especially, when the certainty of punishment by Korean judicial authorities are closely examined, it is believed that there is an inverse relationship between the frequency and the level of seriousness of criminal wrongdoings made by the USFK and the degree of leniency in handling these crimes by Korean judicial authorities, and this hypothesis will be examined by various data shown in the next few sections. But, before going into that matter, the method for this research will be briefly mentioned.

\section{Methodology}

In order to effectively explore are search problem here, this paper is based on the secondary data analysis that investigates what is already known and what remains to be learned about a topic through reviewing sources that others previously conducted in the specified area of interest (Doolan \& Froelicher, 2009). There are many advantages to use secondary data instead of primary data to conduct this research. First of all, in terms of the aspect of cost and time, working with secondary data is cost effective because the data are already collected, cleaned, and stored in electronic format, are searcher can spend the bulk of his or her time analyzing the data (Glaser, 1963; Smith, 2008). Therefore, the use of secondary data can accelerate the pace of research because some of the most time consuming steps of a typical research project, such as measurement and data collection, are eliminated (Doolan \& Froelicher, 2009).

Second, in terms of the quality of the data collection, using secondary data broadens the data available for the research project. One of the biggest challenges for a researcher is to build larger data set, but it is difficult for an individual researcher to have resources to collect data from a representative sample in a macro level, let alone this data collection process every year under the time and financial constraints on the data collection (Smith et al., 2011). Thus, the data collected by funded studies or agencies mostly involve larger sample and contain substantial breadth that are more representative of the target population and allow for greater validity and more generalizable findings (Smith, 2008). In addition, access to this type of data presents opportunities for all researchers, including the unfunded research, that equalize opportunities to build capacity for empirical research (Stewart \& Kamins, 1993). Moreover, using secondary data prepared by experts who specialize in a data collection ensures the quality of research outcomes because the data collection process is often informed by expertise and professionalism that may not available to small independent research projects (Smith et al., 2011). For example, data collection for many federal data sets is often performed by staff members who specialize in that task and who may have years of experience working on a particular survey, while the data sets for many smaller research projects are collected by students working at a part-time, temporary job (Smith 2008).

Lastly, in terms of the accessibility, secondary data analysis allows research on subjects that are not expediently accessible to the public, such as people of old civilizations, the documents from the archives, and the government documents (Boslaugh, 2007). Especially, secondary data sets prepared by federal agencies are more 
easily accessible for funded research or other institutional uses than for the public use. Thus, it might be more efficient for researchers to use pre-existing data sets that are collected and analyzed by experts rather than to endeavor collecting and processing data sets by themselves (Clarke \& Cossette, 2000).

These advantages made me confident in using several secondary data sets in order to examine the trend and type of crimes committed by the USFK and the pattern of judicial exercise made by Korean judicial authorities to handle those crimes. I realized that it was not easy to access those data sets as an individual researcher with no institutional affiliation because additional institutional steps were required to get into those data sets. Therefore, it was more judicious to use the secondary data than making enormous efforts to access the primary data that is not easily accessible for the public, and more importantly it was proved to be a time and cost-effective. In addition, these data sets were prepared by the work of professionals for institutional use who specialize in collecting and analyzing data. So, it guarantees the quality of those data sets. And, I reshaped some of the data sets from those secondary data sources in order to make those data sets fit better for testing for the purpose of this research.

\section{Findings}

Analyzing several secondary data sets clearly indicates that Korean judicial authorities were not effective to control the USFK crimes in 2000s despite the enactment of the second revision in SOFA in 2001. Figure 3 shows the pattern of Korean judicial exercise that is measured by the rate of indictment against the USFK criminals from 2001 to 2010. The pattern clearly suggests that many criminal cases were not indicted by Korean judicial authorities during that time period. Even, the non-indictment rate has increased since 2001 when the SOFA was revised to empower Korean judicial authorities for handling criminal wrongdoings by the USFK. Moreover, the number of crimes committed by the USFK has increased even more rapidly since 2006 even if the size of the USFK has significantly shrunken by as much as 25 percent since 2001.

It means that the Korean judicial exercise under the second revision of SOFA was not still effective to keep the USFK from committing criminal acts, and it is closely related with the fact that the law enforcement exercised by Korean judicial authorities was not certain to punish the USFK for their criminal wrongoings.

And, this lack of certainty of punishing the USFK criminals is also indicated in the type of sentence made by Korean judicial authorities for criminal wrongdoings committed by the USFK crimes. In other words, few USFK who are indicted for a trial proceeding were certainly punished with a prison sentence thanks to the generous judicial exercise by Korean judicial authority, and it encourages the USFK to maintain the pattern of their vicious behavior against innocent Korean citizens.

As shown in Figure 4, the crimes committed by the USFK were not properly handled under Korean judicial system. In other words, the majority of the USFK criminals who appeared before the judge received extremely lenient sentence despite committing serious crimes in Korean society (Kim, 2013). Based on the data collected by South Korean National Police Agency between 2008 and 2012 (n.d.), 85\% of criminal wrongdoings committed by the USFK were sentenced to a fine, and another $12 \%$ were punished with probation or even being acquitted even if they were involved in a felony case. So, only $3 \%$ of criminal cases were punished with a prison

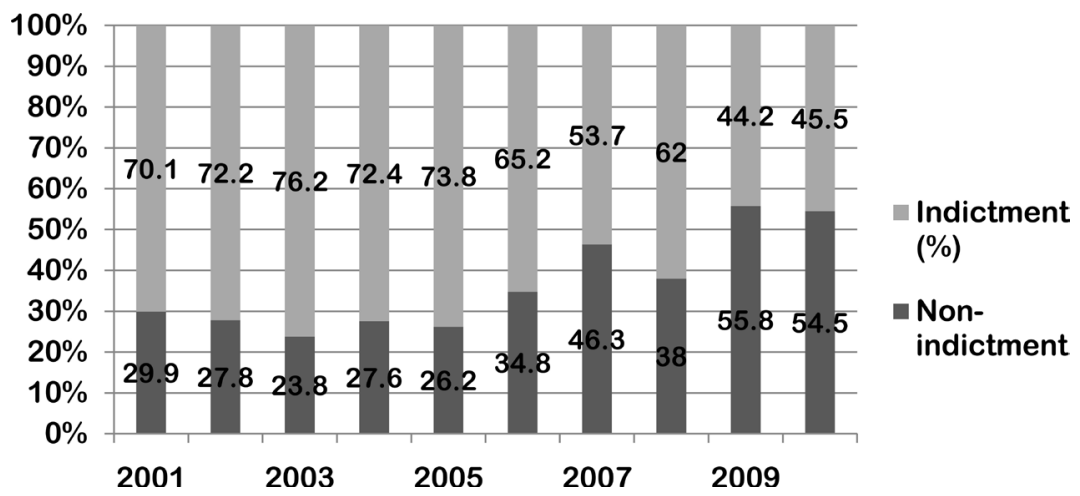

Figure 3. Bar graph showing the type of prosecutorial exercise by Korean judicial authorities for crime cases made by USFK between 2001 and 2010. From “Jurisdiction exercise and SOFA," by I Am Peter (2013). Retrieved from http://impeter.tistory.com/2118. 
sentence. Thus, it indicates that Korean judicial authorities are very generous in treating any criminal cases the USFK involved in when considering the fact that almost half of criminal cases perpetrated by the USKF were felony charges, such as rape, robbery, or even homicide in 2007 and 2008, and that rate even pass 50\% mark in 2010 (South Korean National Police Agency, n.d.). So, it is assumed that despite committing serious crimes against innocent Korean citizens, many criminal cases committed by the USFK were not effectively handled by Korean judicial authorities because the USFK have the extraterritorial rights in Korea that makes Korean judicial authorities to be struggled to exercise their judicial power over the USFK criminals through indicting the USFK perpetrators for their criminal wrongdoings as well as giving an a right sentence if indicted.

The lack of certainty of punishing the USFK perpetrators measured by the type of sentence by the Korean judicial authorities is also confirmed by the pattern of judicial action that handle the USFK perpetrators who are indicted by the Korean judicial authorities. As shown in Figure 5, more than 6 out of 10 USFK personnel who were accused stood summary trial, and there was a gradual increase in the number of USFK perpetrators who stood summary trial rather than formal trial by more than 20\% between 2001 and 2010 (Ahn, 2013).

Previous research suggest that summary trial gives more favorable condition to a defendant thanks to the characteristics of summary trial, such as a strict one-day time limit for hearing, no witnesses, only affidavits and arguments, and being heard by a mini-jury by as few as four jurors that render a verdict at the trial's conclusion. (Lambros, 1986), and it is closely related with the characteristics of the summary trial process that is designed

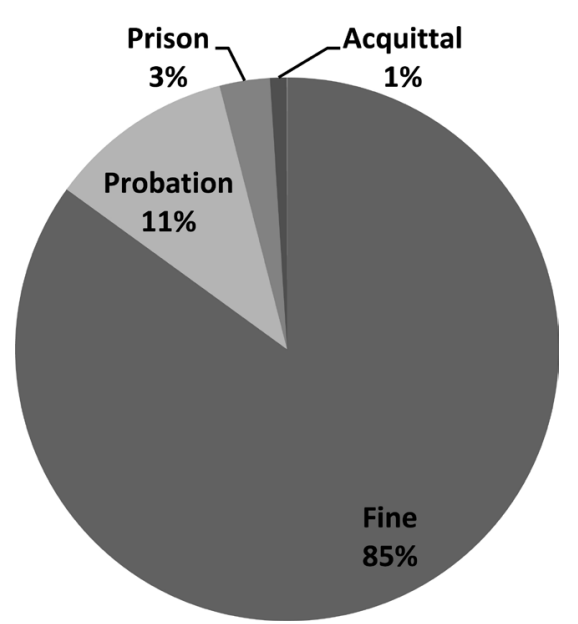

Figure 4. Pie graph showing the type of sentence by Korean judicial authorities for criminal activity committed by US military personnel between 2008 and 2012. From "Only 3\% of USFK personnel being prosecuted by South Korean courts were Imprisoned between 2008 and 2012”, by Kim (2013), Sisa in. Retrieved from http://www.sisainlive.com/news/articleView.html?idxno=15944.

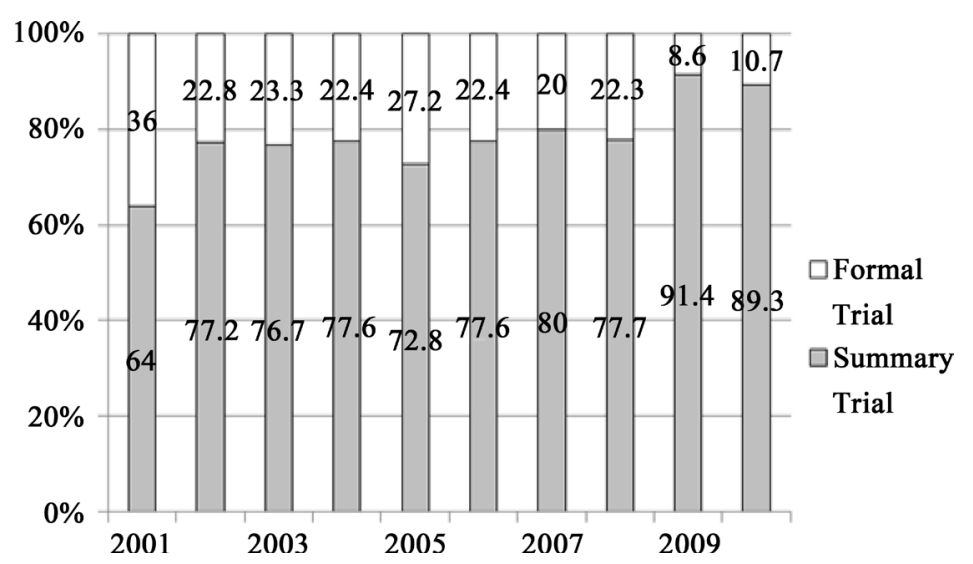

Figure 5. Bar graph showing the type of judicial action used for handling USFK crimes between 2001 and 2010. From "Change in the pattern of crime by USFK”, by Ahn (2013). Retrived from http://www.seoul.co.kr/news/newsView.php?id=20130318009014. 
to be not only quick but also inexpensive (Croley, 2008). Therefore, in a summary trial, many evidentiary rules are relaxed because it usually emphasizes the "summary" and downplay the "trial", and this logic makes more advantageous to a defendant than a plaintiff (Croley, 2008: p. 1588).

Therefore, it strongly suggests that there is a close relationship between the type of sentence the USFK defendants receive and the type of trial they stand. In other words, the reason why the majority of the USFK perpetrators receive light sentences, such as fine or probation despite committing serious crimes in Korean society is partially caused by the fact that the USFK perpetrators mostly stand summary trial rather than formal trial that gives them much more favorable condition in the legal proceedings. This systematic loophole originated by the extraterritorial right of the USFK personnel suggests that Korean judicial authorities are not certain to punish any criminal wrongdoings made by the USFK.

And, the lack of certainty of punishing the USFK crimes by the Korean judicial authorities raises a question why the Korean judicial authorities became incapacitated to punish the USFK perpetrators who should be punished under the Korean judicial system. In the following section, therefore, I will scrutinize a condition in that Korean judicial authorities cannot help but being lenient on crimes committed by the USFK while looking at issues that are relevant to the U.S.-SOFA. Specifically, the following issues will be highlighted a) the unfairness nature of SOFA; b) the process of jurisdiction under SOFA; c) the U.S. and Korean government's attitude toward SOFA.

\section{Discussion}

Based on the result from analyzing several secondary data sources, it strongly supports the hypothesis thatthe impact of the lack of certainty of punishing the USFK perpetrators by Korean judicial authorities increases the criminality of the USFK that is not only frequent and pervasive in terms of quantitative aspect and cruel and cruel and extreme in terms of qualitative aspect.

And, the analysis based on those secondary data sources also indicates that the lenient judicial exercises against the USFK perpetrators were related with by 1) the pattern of prosecutorial exercise by Korean judicial authorities; 2) the type of sentence by Korean judicial authorities and; 3) the type of Korean judicial exercise handling crimes committed by the USFK. In other words, a great number of USFK criminals were rarely indicted by Korean judicial authorities. And, when they were indicted, they were mostly stood summary trial rather than formal trial that gives more advantage to them than Korean judicial authorities. Moreover, the majority of USFK criminals were sentenced to be fined that is extremely generous sentence when considering the nature and cruelty of their criminal wrongdoings against innocent Korean citizens, such as Yoon Kum-I case. Thus, it suggests that Korean judicial authorities were so lenient and powerless that many USFK and other related US civilians easily acquitted from the trials by Korean judicial authority with the exception of few serious crimes, such as rape and robbery because of the lack of the certainty of punishment by Korean judicial authorities, and it made the USFK a major epicenter of many social problems in Korean society.

So, why do Korean judicial authorities have the lack of certainty of punishing crimes committed by the USFK? And, the U. S.-Korea SOFA is the answer for this question because it gives the USFK a special legal treatment, with that Korean jurisdictional authority is prohibited to exercise its jurisdiction on the USFK under the U.S.Korea SOFA. So, USFK are only group among foreigners living in Korea who are entitled to have this special treatment, and this special treatment toward the USFK was made in part by a concession based on the acknowledgment of Korean society in that their presence in Korean peninsula is regarded to have special mission of protecting South Korea from the provocations by North Korea (Kim, 2005).

The U.S.-Korea SOFA is an agreement under Article IV of the Mutual Defense Treaty between the Republic of Korea and the United States of America regarding facilities and areas and the States of United Armed Forces in the Republic of Korea (Korea SOFA, 1966). Generally, when troops are stationed in another country, they must be subject to the legal system of the country they are stationed in according to international law (Dun off and Ratner, 2010). However, the U.S. military has been provided with a reasonable convenience and consideration for performing their particular duties in South Korea and protecting South Korea from North Korea, under the U.S.-Korea SOFA.

SOFA dates back to the latter half of the 1940s. After the Liberation of Korea in 1945, the USFK concluded an agreement, an administrative agreement which was in force during the transition period for the benefit of its military force with the newly established South Korean government, and it was a primitive form of the U.S.SOFA and followed the tradition of the U.S. jurisdiction before the end of World War II in which the U.S. 
maintained complete jurisdiction in military bases abroad based on the principle of the "Law of Flag" (Scoville, 2006: p. 6-7). As a result, Korea had a nominal jurisdiction power over the USFK, and it was effective until 1949 when the U.S. military withdrew from Korea. After that time, the U.S. military were based in South Korean territory when entering Korean War on June, 25, 1950, and Korea concluded an agreement between the Republic of Korea and the United States of America concerning criminal jurisdiction at the cost of their entering a war (Mason, 2012). Upon this agreement, Korea resigned all jurisdictions, related to U.S. military personal. After 1950, crimes committed by U.S. troops were widely prevalent in Korean society, and the Korean government claimed to revise the U.S.-Korea SOFA. After discussions which took thirteen years, the U.S.-Korea SOFA was revised in 1966, and as suggested by the U.S., it ended up with the unequal agreement.

However, when considering the comparative levels of socioeconomic and political maturity between the U.S. and South Korea in 1966, critics argue that South Korea did not have much input in negotiating the terms of the agreement and that this condition made the texts of the U.S.-Korea SOFA unfairly favorable to the United States (CSIS, 2001). In the 1980s, a debate began again about crimes committed by the USFK under the series of democratization movement in Korean society as the part of the pro-democracy movement, and that led to revisions of the U.S.-Korea SOFA in 2001 (Jeong, 2002; Shin, 2001; Koo, 2011). However, the revised bill still had many unequal clauses, and the U.S.-Korea SOFA has never been an effective instrument for controlling crimes by the USFK (Critics Say SOFA, 2000), and it encouraged the USFK to keep committing horrendous wrongdoings against Korean people. In order to understand the unfair nature of the US-Korea SOFA, it is necessary to understand how the USFK are handled by Korean judicial authorities for their criminal wrongdoings.

When the USFK commit crimes, they should be the jurisdiction of Korean authorities. But, Korean judicial authorities must inform the US military authorities of arresting those USFK who are engaged in crimes, and Korean judicial authorities should make a preliminary investigation under the presence of the US military authorities. And then, those USFK are transferred to the US military authorities unless they commit serious criminal offense. When Korean judicial authorities decide to exercise jurisdiction, they have notify the US military authorities of their decision within 28 days after the preliminary investigation. When Korean judicial authorities decide to indict the USFK, they have to notify the US military authorities of the type of trial. However, as long as the USFK do not commit serious crimes, they stand summary trial, and the US-Korea SOFA acknowledge that the right to file an appeal is only in the US military authorities, so Korean judicial authorities are not able to exercise the same right.

Critics argue that this unreasonable nature of criminal procedure is largely caused by the several unfair clauses of the U.S.-Korea SOFA. The most unfair provision regarding crimes committed by the USFK is Article XXII on the jurisdictional exercise by Korean government against the USFK (Korea SOFA, 1966, 2001). This stipulation provides detailed rules on whether Korean authorities or the U.S. military authorities have the primary right to exercise jurisdiction over a crime committed by USFK members, and cooperative procedures between the two authorities in exercising judicial rights including investigation, indictment, trial and execution of rulings (Kim, 2001).

Regarding the question of who should exercise primary jurisdiction, Article XXII specifies two categories of crimes: exclusive jurisdiction and shared jurisdiction (Korea SOFA, 1966, 2001; Hemmert, 1999). Crimes falling under exclusive jurisdiction refer to offenses that are punishable under the laws of only one side (SOFA, 1966, 2001; Hemmert, 1999). For example, crimes such as adultery that constitute a criminal offense under Korean law but do not constitute criminal offenses under US laws are subject exclusively to Korean jurisdiction, and crimes committed in the course of USFK personnel conducting official duties and those committed by one USFK member on other USFK personnel or property are subject exclusively to the US jurisdiction (SOFA, 1966, 2001). And, Crimes under shared jurisdiction refer to criminal offenses that are subject to the jurisdiction of both authorities, and South Korea has priority over the U.S. on exercising judicial power (Korea SOFA, 1966, 2001).

Therefore, it suggests that Korean judicial authorities can exercise its jurisdiction over the majority of criminal acts committed by the USFK in Korean territory (Korea SOFA, 1966, 2001; Jung \& Hwang, 2003). In other words, except for crimes committed in the course of conducting official duties, crimes that clearly have no direct link with official duties, such as assault or robbery during patrols, are subject to the Korean jurisdiction. In short, it seems that the U.S.-South Korea SOFA ensures Korea the right to exercise its jurisdiction over the majority of crimes committed by the USFK in Korea.

In reality, however, there is an obstacle for the Korean judicial authorities to exercise its jurisdiction against crimes committed by the USFK, thanks to the vagueness of Article XXII that gives the U.S. military authorities 
more leverage to negotiate who has the right to exercise the primary jurisdiction. As specified under Article XXII, if the USFK criminals are in the hands of Korean judicial authorities, the US military authorities may request the Korean judicial authorities to transfer jurisdiction over the USFK criminals, and the Korean judicial authorities must take into consideration transferring jurisdiction over the USFK criminals to the US military authorities (Korea SOFA, 1966, 2001; Lee, 2003).

Moreover, if the USFK whose criminal acts are under the Korean jurisdiction are in the hands of the US military authorities, the custody of those accused USFK remain with the US military authorities in that the accused USFK will have to go through legal proceedings under the US military criminal code, and the US military authorities are just required to inform Korean authorities of the status of the proceedings and the ultimate outcome (Korea SOFA 1966, 2001; Lee 2003; Jung \& Hwang, 2003). And, once the Korean authorities decide to exercise jurisdiction, all proceedings including investigation, indictment and trial shall be conducted under the Korean legal system in that the Korean authorities has full control, but Korean judicial authorities rarely ask the U.S. authorities to hand over the USFK to exercise its jurisdiction because Korea must maintain a close relationship with the U.S. that is not only considered as the most important ally but also as the guardian angel for Korea (Jung \& Hwang, 2003).

Therefore, it makes the Korean judicial authorities giving up its jurisdictional sovereignty to the US military authorities on criminal acts committed by the USFK (Lee, 2003), and it is directly related with the attitude of Korean judicial authorities toward criminal acts by the USFK and other US civilians that is fairly lenient compared to crimes committed by Koreans (Jung \& Hwang, 2003). Based on this fact, thus, it verifies the hypothesis that there is a relationship between the jurisdictional incapacity of Korean judicial authorities and the high crime rate among USFK.

Furthermore, the fact in that Korean judicial authorities have trouble exercising jurisdiction against criminal wrongdoings by the USFK is also verified by how unfair the U.S.-South Korea SOFA in comparison with other SOFA treaties the U.S. with other political entities, such as the U.S.-NATO (North Atlantic Treaty Organization) SOFA and the U.S.-Japan SOFA. First of all, there are clauses of 'resignation condition' in the US-Korea SOFA in that the Korean government is mandated to transfer its judicial right to the U.S. military authorities upon request of the U.S. military authority for crimes which belongs exclusively to Korean jurisdiction (Korea SOFA 1966, 2001). A large majority of countries and other political entities including NATO and Japan have a clause to stipulate the matter of jurisdiction over US military personnel, but it is "favorable consideration" which means that they consider the other nation's request in a friendly way not being mandated by the SOFA treaty, so unlike the U.S.-Korea SOFA, those countries have more leverage than the U.S. in the matter of exercising jurisdiction over crimes committed by the USFK (NATO SOFA, 1972; Japan SOFA, 1952; Jung \& Hwang, 2003; Hemmert, 1999).

And, other SOFAs, such as the U.S.-Japan SOFA and the U.S.-Germany SOFA, give those host countries the power to establish the validity of an official duty certificate in that the local court has the power to make final decision on the matter of who should decide whether an injury or property loss caused by USFK is related with the official military duties, while Korean judicial authorities only have the appeal right to intervene in the judicial process because the U.S.-SOFA does not allow Korean judicial authorities to exercise the primary jurisdiction over official military duties of the USFK which are considered as being a subject exclusively to the US military jurisdiction (Kim, 2001; McConnel, 2006).

So, the fact that the U.S.-Korea SOFA is more unfair than other SOFAs suggests that it is more difficult for Koreans to deal with criminal wrongdoings by the U.S. military personnel than people in other countries. Consequently, it led Korean people to insist on denunciating the U.S.-Korea SOFA for the security of their life and rights (Thousands in S. Korea Protest US, 2000).

And, with regards to the matter of custody, Korea is in a much more difficult position to exercise its judicial right than other countries. According to the U.S.-Korea SOFA, the Korean judicial authorities are not allowed to secure the accused USFK into custody when they remain within the U.S. military facilities although those crimes are not exclusively under the U.S. military jurisdiction, while NATO and the Japan are allowed to take the U.S. military personnel into their custody immediately. This is largely caused by the unfair nature of the U.S.-Korea SOFA that the only SOFA treaty that includes” resignation condition” (Erickson, 1994; Gher, 2002; NATO SOFA, 1972; Japan SOFA, 1952). Furthermore, under the U.S. law, criminal proceedings are usually conducted without physical detention of the accused, and that condition makes the Korean judicial authorities exercise their judicial power even more difficult when the accused USFK is in custody under the U.S. military 
authorities. Because of this practice, the Korean judicial authorities in the past have not been able to secure custody until the accused was convicted (Kim, 2001). This kind of unfair structure has caused several light punishments toward the USFK who committed severe crimes, such as murder with rape mentioned in the previous part, and with the massive demonstration among Korean civic organization it led to make another revision of SOFA in 2001 that allowed the Korea judicial authorities to obtain custody as soon as the USFK are indicted for 12 major crimes (Thousands in S. Korea Protest US, 2000; Kim, 2001). However, this revision still did not make the U.S.-Korea SOFA a fair international treaty when compared it with other SOFA treaties, such as the U.S.-Japan SOFA in that there is no limitation on the types of crime for the exercising custody (Norman, 1996).

\section{Conclusion}

This paper has endeavored to find out how and why the USFK became the social pest for Korean society even if they played a significant role in maintaining national security for Korean peninsula because of their role as protecting South Korea from the communist North Korea. In this paper, therefore, I documented the pattern of criminal wrongdoings committed by the United States Military Forces against innocent Korean citizens in Korea and analyzed the ways of exercising judicial power by Korean judicial authorities.

As seen in the findings, the historical trends show that the crime rate was not been significantly dropped in 1990s when the official data for the USFK crime was available, and that trend was not dramatically changes in 2000s even if the size of the U.S. Military Forces in Korea was shrunken at the same time. Moreover, when the types of crime committed by the USFK were considered, the proportion of felony case in the total USFK criminal cases was increased in 2000s, and it approached 50 percent in the late 2000s.

However, the Korean judicial authorities were powerless to control the USFK crime because the USFK criminals were rarely indicted by the Korean judicial authorities. And, the fact that the Korean judicial power was too feeble to deal with this social problem was also proved by the type of the judicial action. For instance, the majority of USFK criminals were sentenced to fine despite committing crimes that were qualified for heavier sentences, and it was partially caused by the fact that they stood a summary trial rather than a formal trial. Based on the deterrence theory, therefore, it clearly suggests that the USFK was motivated to commit many horrendous crimes against Korean citizens because Korean judicial authorities were not too certain to restrain the USFK from committing crimes in Korea.

And, the findings indicate that the lack of certainty of punishing crimes committed by the USFK that is mainly caused by the one-sided nature of the U.S.-Korea SOFA that offers the environment in that Korean judicial authorities which are in a weak position in dealing with crimes committed by the USFK. In other words, Korean judicial authorities are bound by the U.S.-Korea SOFA that is an international treaty Korean government and should observe even if this treaty largely represents the U.S. interests and infringes the judicial right of Korean.

As a matter of fact, the U.S.-Korea SOFA is a treaty from international law, so it should be concluded by the mutual consent under the equality of two nations and must not violate the sovereignty of their fellow country, but Korea has to enter into this treaty with the United States to provide the USFK with the full legal protection in beyond the reasonable bounds because Korea has little political leverage in negotiation with the U.S. that is caused by its status as being heavily dependent on the U.S. for its national security. And, it is true that the USFK still perform a major role of maintaining peace in the Korean peninsula through restraining Korea from the North Korea. Therefore, the USFK infringe the Korean judicial right and it leads the lack of certainty of punishing the USFK perpetrators.

And, the role and size of the USFK has been minimized because of the change in geopolitical condition in the Korean peninsula since the end of the Cold War with the collapse of the soviet Union in 1990, but the presence of the U.S.-Korea SOFA was so influential on the Korean judicial practice that many criminal wrongdoings by the USFK against innocent Korean people were not easily restrained by the Korean domestic law.

In order to better understand why many criminal wrongdoings by the USFK were not controlled by the Korean judicial authorities, thus, it is necessary to more closely scrutinize the U.S.-Korea SOFA treaty. Especially, the future research should be conducted to address the following agenda regarding the U.S.-Korea SOFA: 1) the degree of the unfairness of the U.S.-Korea SOFA by scrutinizing and comparing other SOFAs with the U.S.-Korea SOFA and; 2) the political, economic, and cultural constraints placed on the matter of revising the U.S.-Korea SOFA that helps to make the Korea-U.S. relations more future-oriented. If I could successfully investigate these agenda by looking at the U.S.-Korea SOFA more closely, it might help not only to make the public better understanding the social problem caused by criminal wrongdoings by the USFK but also to give some 
feasible suggestions for the policymakers who would be able to make a better environment for the military operation of the USFK and the wellbeing of Korean citizens.

In addition, the further research should focus on the role of the state on maintaining this uncontrolled pattern of crimes by the USFK because both Korean and the US government can hardly be free from creating this social problem. As suggested by Tombs \& Whyte (2003), the harmful activities of the USFK are produced and sustained by states that regulate, intervene, and mediate in struggles within and between social groups, and ultimately their primary role in structuring social relations.

Especially, this ceaseless pattern of the USFK crimes is mainly caused by the fact in that Korean government has avoided sensitive issues, such as the criminal activities of the USFK and physical and sexual abuse of the women in the military towns and aggressively subdued the demonstration by many Korean civic groups. The reason for the Korean government's cautious posture is twofold: 1) the Korean government in the context of person to person diplomacy wants to retain stable relations with the U.S. and; 2) although Korean government officials consider those crimes an embarrassment, they consider the situation a necessary evil. These attitudes are a direct result of the imbalance of power between the U.S. military and the Korean government and the paternalistic nature of the Korean and American governments. Therefore, it should be better for the further research to focus on the Korea-U.S. relationship and its impact on Korean government's capability to deal with crimes committed by the USFK against its innocent citizens (Moon, 1997; Cho, 2002).

\section{References}

Administrative Agreement under Article III of the Security Treaty, U.S.-Japan, Feb. 28, 1952, 3 U.S.T. 3341 [hereinafter Japan SOFA].

Agreement between the United States of America and the Republic of Korea Amending the Agreement under Article IV of the Mutual Defense Treaty between the United States of America and the Republic of Korea, Regarding the Facilities and Areas and the Status of United States Armed Forces in the Republic of Korea of July 9, 1966, As Amended, U.S.-S. Korea, Jan. 18, 2001 [Hereinafter Korea SOFA]. http://www.state.gov/documents/organization/129549.pdf

Ahn, D. H. (2013). Change in the Pattern of Criminal Activity by USFK. The Seoul Times. http://www.seoul.co.kr/news/newsView.php?id=20130318009014

Baker, A. P. (2004). American Soldiers Overseas. Westport, CT: Praeger.

Beccaria, C. (1963). On Crimes and Punishments (Introduction by H. Paolucci, Trans.). New York, NY: Macmillan.

Bentham, J. (1948). An Introduction to the Principles of Morals and Legislation. Mineola, NY: Dover Publications.

Boslaugh, S. (2007). Secondary analysis for public health: A practical guide. New York, NY: Cambridge. http://dx.doi.org/10.1017/CBO9780511618802

Center for Strategic and International Studies (2001). Path to an Agreement: The U.S.-Republic of Korea Status of Forces Agreement Revision Process. http://csis.org/files/media/csis/pubs/pathtoanagreement.pdf

Cho, G. C. (2002). Sim Mentioned It Is Difficult to Revise SOFA at This Time. Korean Economic Daily. http://www.hankyung.com/news/app/newsview.php?aid=2002112621088

Cho, S. Y. (2003). The ROK-US Alliance and the Future of US Forces in South Korea. Korean Journal of Defense Analysis, 15, 77-104. http://dx.doi.org/10.1080/10163270309464045

Clarke, S. P., \& Cossette, S. (2000). Secondary Analysis: Theoretical, Methodological and Practical Considerations. Canadian Journal of Nursing Research, 32, 109-129.

Critics Say SOFA in Korea More Unfair than Those Elsewhere (2000). The Korea Times. http://www.koreatimes.com/article/6773

Croley, S. (2008). Summary Jury Trial in Charleston County, South Carolina. Loyola of Los Angeles Law Review, 41, 1585-1624.

Deutsch, B. (2008). 2002 Tank Incident and Aftermath. The Korea Times. http://koreatimes.co.kr/www/news/opinon/2008/06/137_26181.html

Doolan, D. M., \& Froelicher, E. S. (2009). Using an Existing Data Set to Answer New Research Questions: A Methodological Review. Research and Theory for Nursing Practice: An International Journal, 23, 203-215. http://dx.doi.org/10.1891/1541-6577.23.3.203

Erickson, R. (1994). Status of Forces Agreement: A Sharing of Sovereign Prerogative. Air Force Law Review, 37, $137-154$.

Facilities and Areas and the Status of the United States Armed Forces in the Republic of Korea, U.S.-South Korea, July 9, 1966, 17 U.S.T. 1677 [hereinafter Korea SOFA]. http://www.state.gov/documents/organization/129549.pdf 
Gher, J. M. (2002). Status of Forces Agreements: Tools to Further Effective Foreign Policy and Lessons to Be Learned from the United States-Japan Agreement. University of San Francisco School of Law Review, 37, 227-256.

Gibbs, J. P. (1968). Crime, Punishment and Deterrence. Southwestern Social Science Quarterly, 48, 515-530.

Gibbs, J. P. (1986). Deterrence Theory and Research. In G. B. Melton (Ed.), The Law as a Behavioral Instrument (pp. 87-130). Lincoln, NE: University of Nebraska Press.

Glaser, B. G. (1963). Retreading Research Materials: The Use of Secondary Analysis by the Independent Researcher. The American Behavioural Scientist, 6, 11-14.

Go, N. M. (2011). Where Is the US Soldier Criminal Who Murdered Yoon Geumee. The Hankyoreh 21, 885. http://h21.hani.co.kr/arti/special/special general/30782.html

Hemmert, S. G. (1999). Peace-Keeping Mission SOFAs: U.S. Interests in Criminal Jurisdiction. Boston University International Law Journal, 14, 215-139.

Hobbes, T. (1962). Leviathan. New York: Macmillan. (Original work published 1651).

I Am Peter (2013). Jurisdiction Exercise and SOFA. [Web Log Comment]. http://impeter.tistory.com/2118

Jeong, W. S. (2002). Candle Lit Rally Commemorates Schoolgirl. The Daily Chosun. Retrieved from nexis.

Jung, S. K. (2008). US to Keep 28,500 Troops in Korea. The Korea Times. http://koreatimes.co.kr/www/news/nation/2008/04/113_22820.html

Jung, Y., \& Hwang, J. S. (2003). Where Does Inequality Come From? An Analysis of the Korea-United States Status of Forces Agreement. American University International Law Review, 18, 1103-1144.

Kim, E. J. (2013). Only 3\% of USFK Personnel Being Prosecuted by South Korean Courts Were Imprisoned between 2008 and 2012. SisaIn. http://www.sisainlive.com/news/articleView.html?idxno=15944

Kim, S. H. (2005). Brothers versus Friends: Inter-Korean Reconciliation and Emerging Anti-Americanism in South Korea. In S. I. David (Ed.), Korean Attitudes toward the United States: Changing Dynamics (pp. 196-219). New York: M.E. Sharpe.

Kim, S. H. (1992). The Tragic Crime by the US Military Servicemen against a Defenseless Korean Women. The Daily Chosun, pp. C1, C11.

Kim, Y. W. (2001). The Past and the Present of the SOFA. In Y. K. Oh (Ed.), The Order of International Law in the 21st Century: Theories and Practices in the Eyes of Diplomats (pp. 124-25). Seoul: Pakyoungsa.

Kirk, D. (2002). Road Accident Galvanizes the Country: Deaths in Korea Ignite Anti-American Passion. The New York Times. http://www.nytimes.com/2002/07/31/news/31iht-kor_ed3_1.html

Ko, N. M. (2011). Where Is a USFK Criminal Who Brutally Murdered Ms. Yoon? Hani21. http://h21.hani.co.kr/arti/special/special_general/30782.html

Koo, J. H. (2011). The Uncomfortable SOFA: Anti-American Sentiments in South Korea and The U.S.-South Korea Status of Forces Agreement. American University National Security Law Brief, 1, 103-115.

Lambros, T. D. (1986). Summary Jury Trial: Alternative Method of Resolving. Judicature, 69, 286-290.

Lee, Y. H. A. (2003). Criminal Jurisdiction under the US-South Korea Status of Forces Agreement: Problems to Proposals. Journal of Transnational Law \& Policy, 13, 213-249.

Mason, R. C. (2012). Status of Forces Agreement (SOFA): What Is It, and How Has It Been Utilized. https://www.fas.org/sgp/crs/natsec/RL34531.pdf

McConnel, I. R. (2006). A Re-Examination of the United States-Japan Status of Forces Agreement. Boston College International and Comparative Law Review, 29, 165-174.

Moon, C. (1997). Sex among Allies: Military Prostitution in U.S.-Korea Relations. New York: Colombia University Press.

National Campaign for Educational of Crimes by U.S. Troops in Korea. (n.d.). Crimes by USFK in Korea [Data File]. http://usacrime.or.kr/doku/doku.php?id=start

National Police Agency. (n.d.). Annual Survey of Crimes in Korea [Data File]. http://www.police.go.kr/assembly/bbs/list.do?bbsId=B0000061\&menuNo=800002

Norman, A. B. (1996). The Rape Controversy: Is a Revision of the Status of Forces Agreement with Japan Necessary? Indiana International \& Comparative Law Review, 6, 717-740.

Neff, R. (2010). Kenneth L. Markle: Sadistic Murderer or Scapegoat?

Scoville, R. (2006). A Sociological Approach to the Negotiation of Military Base Agreements. University of Miami International \& Comparative Law Review, 14, 1-64.

Shin, Y.-B. (2001). New SOFA Takes Effect. The Korea Herald. Retrieved from nexis. 
Smith, E. (2008). Using Secondary Data in Educational and Social Research. New York: McGraw-Hill Education.

Smith, A. K., Ayanian, J. Z., Covinsky, K. E., Landon, B. E., McCarthy, E. P., Wee, C. C., \& Steinman, M. A. (2011). Conducting High-Value Secondary Dataset Analysis: An Introductory Guide and Resources. Journal of General Internal Medicine, 28, 920-929. http://dx.doi.org/10.1007/s11606-010-1621-5

Snyder, S. (2009). Pursuing a Comprehensive Vision for the US-South Korea Alliance. http://www.csis.org/media/csis/pubs/090409_snyder_pursuingcompvision_web.pdf

Status of Forces Agreement, with Appendix, between the United States of America and Other Governments, June 19, 1951, 4 U.S.T. 1972 [hereinafter NATO SOFA].

Stewart, D. W., \& Kamins, M. A. (1993). Secondary Research: Information Sources and Methods. Newbury Park, CA: Sage.

Thousands in S. Korea Protest US. (2000). Los Angeles Times. http://Articles.latimes.com/2000/jul/26/news/mn-59376

Tittle, C. R. (1969). Crime Rates and Legal Sanctions. Social Problems, 16, 409-423. http://dx.doi.org/10.2307/799950

Tombs, S., \& Whyte, D. (2003). Scrutinising the Powerful: Crime, Contemporary Political Economy and Critical Social Research. In S. Tombs, \& D. Whyte (Eds.), Unmasking the Crimes of the Powerful. New York: Peter Lang.

U.S. Department of Defense (2010). Base Structural Report [Data File]. https://kb.defense.gov/app/answers/detail/a_id/67

$\mathrm{Xu}, \mathrm{T}$. (2007). US-ROK Alliance: Looking toward the Future. In 2007 SAIS US-KOREA Year Book. http://uskoreainstitute.org/wp-content/uploads/2010/05/YB07-Chapt2.pdf 